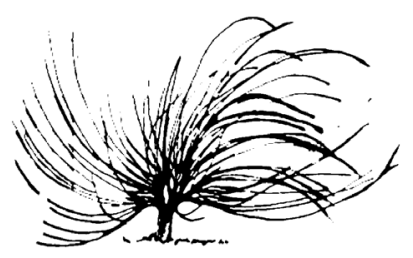

\title{
Fourth-Year Student Reflection of their Learning Process in the English Teaching Major at Universidad Nacional: A Case-Study of their Perception
}

\author{
Ana Rojas Ugalde \\ Escuela de Literatura y Ciencias del Lenguaje \\ Universidad Nacional \\ Costa Rica \\ ana.rojas.ugalde@una.ac.cr \\ Giannina Seravalli Monge $e^{2}$ \\ División de Educología \\ Universidad Nacional \\ Costa Rica \\ giannina.seravalli.monge@una.ac.cr
}

\begin{abstract}
This research was conducted with a group of 37 senior students from the English Teaching major at Universidad Nacional (UNA) in 2018, as a way of getting some important feedback of their learning process perception in order to improve the study program's scope and design. The main objective was to recognize the strengths and weaknesses of the major directly from students' voices to define which areas need improvement as valuable input to be considered in a future curricular redesign that could
\end{abstract}

Recibido: 10 de diciembre de 2019. Aprobado: 2 de setiembre de 2020.

http://dx.doi.org/10.15359/rep.16-1.14

1 Profesora de inglés como lengua extranjera, Escuela de Literatura y Ciencias del Lenguaje, UNA, máster en Segundas Lenguas y Culturas, Universidad Nacional.

2 Profesora de los cursos pedagógicos en la Enseñanza del Inglés, División de Educología, UNA, máster en Administración Educativa, Universidad de Costa Rica, con más de 20 años de experiencia. 
meet UNA's standards and professional profiles. The methodological strategy used included interviews and questionnaires, as well as the analysis of theories on language learning and teaching and affective and motivational factors in order to analyze if the content included in the major's curriculum has fulfilled students' expectations towards their professional demands. Some of the conclusions show students' high degree of satisfaction towards the major; however, they mention important weaknesses on evaluation procedures and on content. These findings become a valid starting point to create a future introspective exercise considering some improvements this program should undergo in a future redesign process. This study could be replicated in other university majors that want to improve their own academic offer.

Keywords: language learning, students' perception, English as a foreign language, motivation, teaching strategies, teaching processes

\section{Resumen}

En el año 2018, se recopiló información de 37 estudiantes de cuarto año de la carrera del Bachillerato en la Enseñanza del Inglés (BEI) de la Universidad Nacional (UNA), para obtener sus percepciones acerca del proceso de aprendizaje vivido y mejorar el diseño y alcance del programa de estudios. El objetivo principal fue reconocer fortalezas y debilidades de la carrera desde la voz de los educandos y por ende contar con información valiosa para un futuro rediseño curricular que cumpla con los perfiles y los estándares de la UNA y del mercado profesional. La estrategia metodológica incluyó la entrevista y el cuestionario, así como el apoyo en teorías basadas en el aprendizaje y la enseñanza de un idioma y en factores motivacionales y afectivos con el fin de analizar si el contenido incluido en el currículum cumple con las expectativas de los estudiantes en sus demandas profesionales. Algunas conclusiones revelan que estos sienten un alto grado de satisfacción con el programa; sin embargo, mencionan áreas débiles como en la evaluación y en algunos contenidos. Estos hallazgos podrían servir de base para un futuro rediseño curricular de la carrera, así como 
podría ser replicado en otras especialidades como parte de sus propias mejoras en la oferta académica.

Palabras clave: aprendizaje de un idioma, percepción del estudiante, inglés como lengua extranjera, motivación, estrategias de enseñanza, procesos de enseñanza.

\section{Introduction}

$\mathrm{s}$ an accredited program, the English Teaching major at
Universidad Nacional (UNA) Omar Dengo Campus, requires
constant evaluation of its results. In this sense, analyzing students' process and outcomes at the end of their bachelor's degree becomes a necessity that is not always considered. UNA's mission and vision statements place students as the focus and center of the educational process, highlighting the academic excellence the university has (Universidad Nacional, 2019). Hence, as an accredited major by SINAES ${ }^{3}$, we scholars and researchers must be committed to evaluating and improving our courses constantly and mainly if we are looking forward to redesigning the major. Therefore, this study aims to know students' perception of the learning process they experienced in the English Teaching major, Bachillerato en la Enseñanza del Inglés (BEI, for its acronym in Spanish), during the four years of the program.

\section{Elements in a Successful Program}

The following section presents a synthesis of the information gathered in two accredited language programs from UNA in which students' perception was also collected to detect stronger and weaker areas. Also, the authors address some theories and principles on language learning and teaching that are key elements in the language program analyzed, such as language learning and acquisition, motivation, the humanistic view on language learning, and excellence.

\section{The Accreditation Process}

For a language program to be accredited, there are several requirements it must fulfill. One of them is the possibility to open efficient

3 Costa Rican National Accreditation System of Higher Education Quality (for its acronym in Spanish) 
and reliable spaces where students can express their opinion about the academic processes that they have been through. The collected information comes from two accredited teaching language majors at UNA: French and English. In the French area (Universidad Nacional, 2015), $67.86 \%$ of students consider they feel free to express their opinions and, in the case of the English major, $86.75 \%$ of students feel they can openly express their opinion about the major, courses, professors, facilities, among other aspects related to the major (Universidad Nacional, 2018). Another aspect has to do with the degree of satisfaction with the major. In the French area, $85.11 \%$ of students feel satisfied with the major (Universidad Nacional, 2015) and the English one, 99\% of students express the same (Universidad Nacional, 2018). It is evident that in both majors, there is a desire for giving students opportunities for expressing their opinion towards their professional growth. With this background information, it could be possible to establish a pattern and to provide continuous feedback to the major on students' degree of satisfaction towards it at least in the English area.

According to the data collected for this specific research, the major was assessed by the students as a successful learning experience in which these learners state they have reached their desired objectives as well as the ones established in the curriculum. Therefore, considering the information provided by students, the following theories are part or have been part of the content, methodology, and practice used in their four-year process in this major. Hence, students feel they have greatly improved their language level as well as their skills to become successful language teachers; they have been motivated throughout their learning process and have made special emphasis on the humanistic part reflected in the methodologies professors use. Based on these considerations, the theories that are present, possibly among others, to reach such positive results and feedback from students at the very end of their major, are the ones that follow.

\section{Language Learning and Acquisition}

Firstly, learning and acquisition take place when learners are exposed to meaningful content. It means that when students can relate the new input to prior knowledge to make connections, this then results in meaningful learning and acquisition rather than rote learning (Ausubel, 2000). Therefore, if the teaching methodologies allow students to 
connect what they are being taught with their immediate environments and realities, the new information can be easily linked with their previous experiences. For example, during the Innovation, Field Research in English course, and Educational Production Seminar, students must propose an innovation to benefit a public or private educational institution. They are required to base their project on observations and their teaching practicum experience to carry out their assignment. Hence, they must use a previous experience to create a tool which can aid the situations observed, not a random hypothesized context, classroom situations which present a disadvantage or problem, such as lack of motivation from students or teachers, classroom management, evaluation techniques, and others. By doing this, students can analyze in depth and state specific contexts which require action to improve them. Examples such as these promote motivation because students learn in a meaningful way by using their reality to critically create, propose, and suggest projects to address needs previously observed in a classroom. This task highly motivates students as they become involved in the teaching and learning processes as agents of change.

\section{Motivation}

Motivation is a key factor, which is connected to Ausubel's theory, considering that students are exposed to meaningful learning, they will be motivated because the information or context is relevant for them (2000). Cavanagh stated

If you want to capture attention, harness the working memory, bolster the long-term retention, and enhance the motivation of your students, considering the emotional impact of various aspects of your course design is one of the best approaches you can take. (2016, p. 212)

The implementation of those elements will develop students' inner driving force towards learning. If the teaching and learning processes are given in a humanistic environment, students will be more motivated and open to self-actualize and achieve their own potential (Rogers, 1977).

"Krashen claims that learners with high motivation, self-confidence, a good self-image, a low level of anxiety and extroversion are 
better equipped for success in second language acquisition" (Schûtz, 2019, para. 9). This low level of anxiety can reduce students' affective filter to avoid blocking input necessary for acquisition, and it can be activated through several situations in which learners can be exposed. As Krashen pointed out (1986), the affective filter is a metaphor that describes a learner's attitude that affects his or her relative success of second language acquisition.

As we will see in the results, most students feel highly motivated and challenged by the different courses. If students are faced with situations, they consider challenging but not threatening, they will acquire more language even a little bit beyond their current level of competence $(i+1)$ (Sole, 1994). This experience provokes in the learners a feeling of self-achievement and independence from the native language. Students recognize their strengths and weaknesses and become aware of their own learning process with the help of context or extra-linguistic information.

\section{The Humanistic View on Language Learning}

Accompanying students' learning process with a humanistic and supportive learning environment will enhance their talents and improve their own language learning processes. As mentioned by Rogers (1977), a humanistic approach emphasizes looking at the whole individual and stresses concepts such as free will, self-efficacy, and self-actualization. Rather than concentrating on dysfunction, this approach strives to help people fulfill their potential and maximize their well-being. This method, in addition to a reinforcing student-teacher relationships, will create a beneficial learning environment for students and teachers as well. At UNA, humanistic approaches are central theories to be developed and experienced by students in their learning processes; however, as we will later see, this is not always achieved by all professors.

\section{Excellence}

Another relevant aspect for a school program to be successful is the correlation it possesses with the final examinations of international ranking. In this case, the sample group of students from the BEI took the Test of English for International Communication (TOEIC) that certifies their language proficiency at an international level in which almost all students got a very high-level ranging from $\mathrm{B} 2$ to $\mathrm{C} 1$. These 
ranks are based on the Common European Framework of Reference for Languages (CEFR). This is a valid and reliable proof of the academic excellence that has been present in the major in a holistic way during the four years. Part of evaluating a program is to recognize its impact or outcomes in society and the demands and priorities of the stakeholders. In this sense, considering students' voices as a focus group will determine challenging issues and further research areas.

\section{Methodology}

\section{Paradigm}

This research responds to a naturalistic paradigm where the phenomena are studied in the same context where it is happening. It required the interaction of the researchers with the informants in that way it was possible to identify the real needs of the sample population. As Creswell stated (2013, p. 73), "naturalistic researchers gather up-close information by actually talking directly to people and seeing them behave and act within their context. In the natural setting, the researchers have face-to-face interaction over time."

\section{Approach}

By using a phenomenological approach without any preconceived notion or expectation, the researchers wanted to focus on the commonality of a lived experience within a particular group (Creswell, 2013). In this case, the researchers chose this specific population because most of them have been in the major since the first year, and they could become valuable informants due to their experience. Also, they happened to be in the very last course of the major. All these conditions created a proper scenario for conducting the research in the learners' natural classroom environment.

\section{Design}

Through a qualitative design of a case study, students' perspectives about their learning experiences were documented. This exploration is crucial because it gives us the chance to study a group or population, identify variables that cannot be easily measured, or hear silenced voices (Creswell, 2013). We conduct qualitative research in a case study design when we want to "empower individuals to share their stories, hear their voices, and minimize the power relationships 
that often exist between a researcher and the participants in a study" (Creswell, 2013, p. 77).

\section{Participants and Context}

The 37 students that took part in this research were taking the course Innovation, Field Research in English, and Educational Production Seminar, which is the last course of the major on English Teaching at Omar Dengo Campus. The study was conducted with 22 female and 15 male learners between 20 and 59 years old.

\section{Procedures and Instruments for Data Collection}

The procedure to collect information was carried out in three parts. Firstly, all the participants were informed about the objectives of the research and the confidentiality policy. Secondly, voluntarily all the participants were informally interviewed to obtain a general and holistic perspective of their opinion about their English teaching major learning experiences throughout the four years of study. Then, their answers were classified in terms of positive or negative experiences. In semi-structured interviews, the interviewer has more flexibility when it comes to adding questions or asking for clarifications. They facilitate the collection of personal data, given that the participant feels more comfortable and relaxed, making the interview more of a conversation than a calculated interrogation of questions and answers (Canals, 2017).

Thirdly, the students completed a written survey through Google Forms for which answers were carefully analyzed and presented in the data analysis below. According to Canals, surveys can be part of more extensive interviews (2017). The survey was anonymous, and it included four areas: general information, work and study, evaluation of professors, and courses. It contained 11 closed questions and 10 open-ended questions which provided information regarding their experiences of studying in the major. The fourth part consisted of the analysis of the results in the TOEIC examination that the students took at the end of the major for the purpose of studying outcomes that mirror their competence through performance, and which allows us to make correlations and analyze their perspectives in terms of accomplishments. 


\section{Validity and Triangulation Process}

To verify the validity of the data collected, students were asked in what year they had entered the major, and from the 37 students, 30 of them said that they had started since the first year; that is, they have concluded the four years that the major requires. From the seven remaining students, five became enrolled in the second year, whereas the other two did not provide this information.

As part of the triangulation process, this study used the data triangulation method using two different instruments (questionnaire and interview) and the results from a high-stakes examination (TOEIC). This process led us to deduce common characteristics or opinions to reach conclusions.

\section{Data Analysis}

Once the interviews and questionnaires were applied, our first step was to gather students' general perception of satisfaction or dissatisfaction with the process they had engaged in. Out of the 37 students, only one is dissatisfied with the major and the way they are guided until this last course. This preliminary result demonstrates that the majority is fully satisfied with the process they have been part of. After obtaining this result, it became imperative to study the reasons for this general belief and find possible flaws to overcome and grow in our major. Within our analysis, it was crucial to explore the working environment for our graduate students, which, in the end, is a great part of what they are being prepared for. Seventy two point ninety seven percent (27 students) of this group reported to be currently working, 22 of them in educational language institutions, such as Centro Cultural Costarricense Norteamericano, Intens $a^{4}$ and other private institutes, and seven pupils in a non-educational place (call centers, Uber, among others). The remaining ten learners did not report to be working at that time. In essence, the majority of the students in this course were working in recognized educational settings at the time they were taking the last course of their major. This reflects their optimal performance as educators considering that they were in a process with other candidates who aimed for the same positions. This study shows that the students in this

4 Centro Cultural Costarricense Norteamericano and Intensa are two important private language institutes in Costa Rica 
major are well received in the labor market. In addition, an element that stands out is the information collected regarding the proficiency level they consider they had when they entered compared to the one they have at the end of the four years. The latter can be proven with the TOEIC results.

\section{Figure 1}

Students' Appraisal of their Approximate Proficiency Level when they Entered the Major

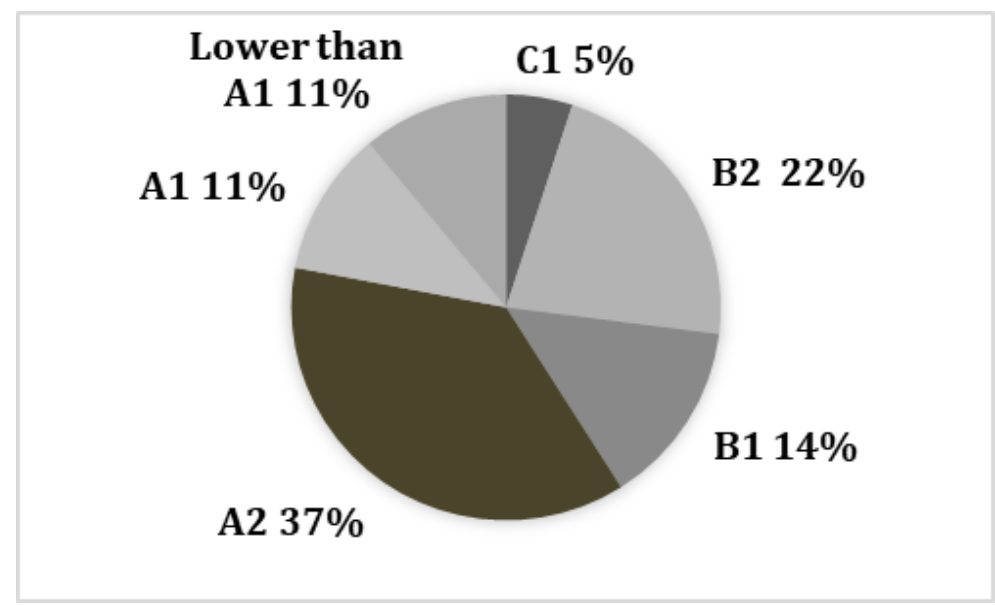

Note: The achievement ranks correspond to the CEFR levels (Researchers' own elaboration).

Figure 1 shows how more than half of the students, $59 \%$, considered they had a very low language proficiency level (A2 or lower) when they entered the major. Thirty-six percent placed themselves at an intermediate level, and only 5\% (two students) stated they have been a $\mathrm{C} 1$ from the start. It is noticeable how the majority of students enter the major with a very low level in the target language, but this was not an obstacle for continuing their studies and mastering the foreign language by relying on the curricular foundation of the major. 


\section{Figure 2}

Students' Perception of their Proficiency Level in 2018

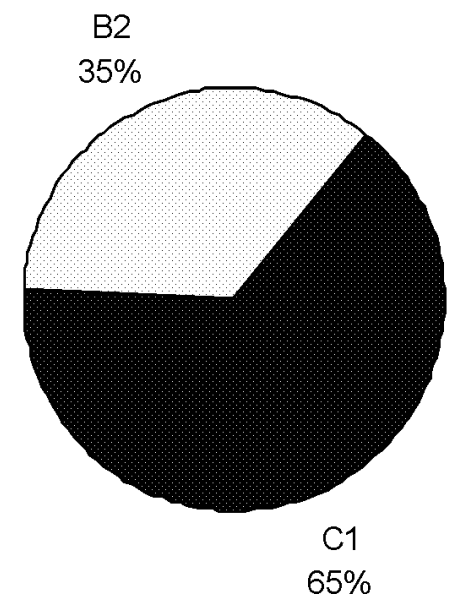

Note: This represents the level students perceive they had after four years of studies (Researchers' own elaboration).

Figure 2 shows a great difference compared to Figure 1. One hundred percent of the students place themselves at the highest levels for language competence and performance. This clearly demonstrates that students feel that they have greatly improved their level of English, and that the major has made a difference in their learning processes as they place themselves in the highest ranks of the TOEIC scale. This information, compared to figure 1, leads us to state that the curricular offer in the major is perceived by students as successful in the sense that they can notice a positive change in their target language level. Later, this perception will be confirmed by an external international test (TOEIC).

The questionnaire provided a section for students to refer to the professors and their methodologies and how they contribute to their learning. Although each professor is different, the intention was to analyze how students perceive the teaching methods and the humanistic vision that this university intends to go by. The courses were also analyzed in terms of contents and the learning that took place in order to reach the students' current language learning-teaching competence and performance. 


\section{Results Concerning the Professors}

The recorded data showed that $78.3 \%$ of the students highly rely on their professors' knowledge, $13.5 \%$ said they sometimes did, and $8.1 \%$, which corresponded to only three students, stated that they did not rely on their professors' knowledge. Two of these three students emphasized that their response was due to their obligation as students to become researchers, and the remaining student said that he does not have a need for it (See first three reasons below).

Some of their reasons were the following: ${ }^{5}$

1. Many times I learn on my own, I am able to look for other means to understand something. While I appreciate everything a professor teaches me, I do not solely rely on them; I have to put some effort into learning.

- I like to do my own research on areas I think I need to improve.

- $\quad$ Because I already have some knowledge teaching plus all the time I have been studying English in different institutions.

- They know about the area but some of them do not know how to transmit it.

- I believe professors have knowledge in English and in pedagogy.

- I have no complaints about my professors. They've been the best mentors one could have ever had. Every time I asked questions they were all answered properly.

- Most of the time they seem to be well-prepared and they actually explain and give feedback based on their knowledge.

- $\quad$ They are not a walking dictionary yet they are supposed to know the subject.

- Most of the time professors in this university are very professional, they know the topics and explain them in the correct way. Most of them push us to think critically.

- $\quad$ Sometimes they base their knowledge on their own perspectives and beliefs

5 Sentences are literally transcribed from the students' written responses. 
- $\quad$ They have demonstrated that they know a lot.

- $\quad$ Putting aside the fact of liking them or not, I truly believe that being a professor at UNA requires him/her to be very skilled and well formed.

Additionally, students were asked if their professors provided a good model to follow in their future professional life. Seventy-point three percent of the class agreed that most or all the professors did. Twenty-four-point three percent said some of them did, while only $5.4 \%$ (corresponding to two students) said few of them did. This information revealed that learners feel the professors of the major are proper guides and models to follow professionally.

The following statements show students' degree of satisfaction towards the major; some of their comments related to the question are the following: 6

- $\quad$ Most of them love what they do.

- $\quad$ Some professors have been an important key in this major.

- They all show that they have worked hard to get to where they are.

- Most of the time, they are willing to help and guide the students. Besides, they are always looking to give pieces of advice to help us to improve.

- $\quad$ They are very professional and well- educated.

- $\quad$ I have had very nice experiences with all of my professors and they have marked me in many different ways. There are role models I would like to follow when I get to teach.

- $\quad$ Most of them seem to be the ideal professor, full of knowledge and humanity

- $\quad$ They provide valuable information, they are very ethical, and I would like to teach as some of them do.

- There are always exceptions and behaviors that I consider inappropriate for a professor. However, the great majority of my professors have been amazing and I have enjoyed their teachings.

- $\quad$ They have taught us to be persistent and fight to get what we want.

- $\quad$ They have always behaved in a polite and respectful way.

6 Sentences are literally transcribed from the students' written responses. 
- $\quad$ There are teachers that have pushed me to give the best of myself since they are really good.

- $\quad$ Most of them gave me great advice during the major, yet other ones just acted as if nothing mattered.

- $\quad$ Some of them are very creative in their classes and had an impact in my learning process.

- Most of them have been responsible and have demonstrated interest in helping

- $\quad$ Students develop a correct use of the language and good research abilities.

- I'm very satisfied with most of the professors that I've had because I've learned a lot from them and not just academically speaking. Most of the professors are amazing.

\section{Results Concerning the Courses}

Table 1 shows students' degree of satisfaction. Sixty-two-point one percent of students stated they are satisfied and strongly satisfied with the courses received in the major. Thirty-five-point one percent are neutral, while only $2.7 \%$ (1 Student) feels dissatisfied. Therefore, there is a majority of students who feel they have learned and improved in the courses of their major. 
Fourth-Year Student Reflection of their Learning Process in the English

Teaching Major at Universidad Nacional: A Case-Study of their Perception

Table 1.

Degree of Satisfaction with the Given Courses

\begin{tabular}{|c|c|c|}
\hline Positive Feedback & $\begin{array}{l}\text { Negative or Neutral } \\
\text { Feedback }\end{array}$ & Negative Feedback \\
\hline $\begin{array}{l}\text {-I have learned and gained } \\
\text { many insights regarding } \\
\text { the grammar and usage of } \\
\text { English. } \\
\text {-I've compared my history } \\
\text { of courses to other people's } \\
\text { from other universities and } \\
\text { I feel happy I made the right } \\
\text { decision to major at UNA. } \\
\text {-I am strongly satisfied with } \\
\text { the education and prepara- } \\
\text { tion on the English major } \\
\text { as well as on the education } \\
\text { courses. } \\
\text {-I really learned how to plan } \\
\text {-I've learnt more about } \\
\text { English language during the } \\
\text { last } 6 \text { years at UNA than at } \\
\text { any other stage in my life. Of } \\
\text { that I'm sure } \\
\text {-I keep on learning and more } \\
\text { importantly, the courses have } \\
\text { made me want to learn more. } \\
\text {-I have enjoyed all my } \\
\text { classes. } \\
\text {-Most of the academic curri- } \\
\text { cula is well structured. } \\
\text {-I am strongly satisfied since } \\
\text { I have learned a lot in each } \\
\text { course in many aspects. } \\
\text {-I've enjoyed almost all of } \\
\text { the courses and I've learned } \\
\text { a lot. }\end{array}$ & $\begin{array}{l}\text {-Many seemed unne- } \\
\text { cessary or not well } \\
\text { planned but others } \\
\text { taught me things I } \\
\text { will never forget. } \\
\text {-Some courses } \\
\text { should be taught } \\
\text { virtually. }\end{array}$ & $\begin{array}{l}\text {-Some courses are repetiti- } \\
\text { ve, and unnecessary. } \\
\text {-Some of them could have } \\
\text { had a better formative eva- } \\
\text { luation. They most of the } \\
\text { time they do not provide } \\
\text { formative assessment. } \\
\text {-Some of them are repeti- } \\
\text { tive, and they are work we } \\
\text { already did. } \\
\text {-I personally believe that a } \\
\text { few courses are not neces- } \\
\text { sary or are not developed } \\
\text { in the best way possible. } \\
\text { Some courses are based on } \\
\text { just giving speeches and } \\
\text { that has become something } \\
\text { too repetitive at this point } \\
\text { of the major. Also, there } \\
\text { are some courses where } \\
\text { professors are only interes- } \\
\text { ted in the content (which } \\
\text { is something good), but do } \\
\text { not seem to be interested } \\
\text { in providing any more fee- } \\
\text { dback related to students' } \\
\text { proficiency level. } \\
\text {-There are some courses } \\
\text { that are related to others } \\
\text { and that I think are not so } \\
\text { relevant such as culture and } \\
\text { intercultural communica- } \\
\text { tion. Maybe with the first } \\
\text { one, it will be enough. }\end{array}$ \\
\hline
\end{tabular}

Note: Students actual writing mistakes were literally transcribed (Researchers' own elaboration). 
Although most students claim to feel satisfied with the courses, their opinions are the most valuable data since that provides insights into what seems to be well-accepted by students while providing positive results, and what seems to be the weaknesses that need to be strengthened. Also, students mention possible solutions for improving the weaknesses, such as including more formative evaluation and less weight on content as an end. Furthermore, students were also asked if they felt prepared to face real classroom environments for which an $83.7 \%$ responded positively. An $8.1 \%$ said they felt prepared, and another $8.1 \%$ indicated they were not so prepared, while $0 \%$ was listed in the poorly prepared section.

Most of the students emphasized that the mini practicum they did during their second year of the major was a very useful and enriching experience. They feel prepared although they feel inexperienced, which is normal in that beginning stage. The final question was if they, the students, would recommend this major to others. The result was that $97,3 \%$ of the group indicated that they would recommend the major to others; only $1,7 \%, 1$ student, said the contrary. It is crucial to emphasize that almost $100 \%$ of the group feels that their educational process has been enhanced, and that studying in this major has meant professional growth and excellence.

In this way, their feelings of professional growth and learning go hand in hand with the results obtained in the TOEIC exam at the very end of the major. Thirty five out of the thirty-seven students took the test; the reasons why two students did not take the test are unknown. The results are as follows: 30 students achieved a $\mathrm{C} 1$, four got a $\mathrm{B} 2$, and only one obtained a B1. These promising results reveal a long process of hard work and commitment from all the participants in this major that somehow can be improved.

\section{Conclusions}

The collected data show that the sample of learners who participated in this analysis have valid information for this research considering that a great majority of them have been part of the process from the beginning of the first year of this major. Considering the main objective of this research, some strengths and weaknesses from the English teaching major at Omar Dengo Campus can be stated: 


\section{Strengths:}

- $\quad$ Students are mostly satisfied with the results they obtained from the major. All of them expressed that their initial level of English has improved.

- $\quad$ Students perceived that this major has offered them the necessary pedagogical and linguistic tools for facing their future working life.

- The high scores students received at TOEIC demonstrated that the process throughout the major does provide the tools for students to reach successful outcomes.

- Most students obtained high grades on the TOEIC test, giving them more job and study opportunities.

- $\quad$ Students considered that most of their professors are good professional models to follow.

- $\quad$ Students highly trust their professor's knowledge.

- $\quad$ Students expressed that this major has provided them with professional growth and excellence.

- $\quad$ Apparently, the theoretical foundations and principles present in the major for the teaching and learning of a foreign language have been perceived by the students as a positive element in the whole process. This becomes evident when most students expressed that they feel very satisfied with the process they underwent when learning a foreign language and the development of the necessary skills to teach it.

\section{Weaknesses:}

- $\quad$ Students complained about some professors' attitudes within the learning and teaching processes that could hinder the humanistic perspective.

- $\quad$ Students suggested that some areas of knowledge, such as special needs are left aside in the curricular program. Students claim they need more preparation in that regard.

- Another important issue to be taken into consideration is the repetition of content among courses. Students mentioned that in some courses along the major, the same content and reading sources are used indistinctly.

- Furthermore, students claimed that some courses need more practical evaluation and more on-going assessment. 
Considering all the previous analysis, it is concluded that the major is a strong one and leads learners to the place they need to be in. Some of the limitations were that a few students had difficulty putting all the courses and professors at the same level or category, when answering the survey, since they felt some courses surpassed others in terms of contents and the learning that took place, while others have weaknesses to be improved. Moreover, it is difficult to control the students' participation, such as the fact that two students did not take the TOEIC exam, and it was not possible to obtain their reasons.

Although some limitations were present, crucial data were collected to establish a starting point of analysis for the future redesign of the major. Students' voices are many times ignored and through studies like this, they could have a chance to be heard, spread, and included for benefit of significant changes in the major. Furthermore, it is sought to collect information from coming generations to analyze if similar patterns are shown. Also, the inclusion of the analysis of other elements and studies which include materials and the use of technological tools in the class could be eye-opening for the intended results of our major.

Considering all the previous analysis, it is concluded that the major is a strong one and leads learners to the place they need to be in. However, improvements can be made, and most importantly students have many opinions and views of their own that sometimes are not evident for those who are on the other side. As a final recommendation, by sharing reflections of the learning process in the English teaching major directly from the students' voices in their last school term, other schools in our university and in others, could replicate this process and could greatly benefit by analyzing the strengths and weaknesses gathered in the obtained data. This analysis could lead administrators and professors into the pursuit of successful university programs. 


\section{References}

Ausubel, D. (2000). The Acquisition and Retention of Knowledge: A Cognitive View. Springer Publishers. https://doi. org/10.1007/978-94-015-9454-7

Canals, L. (2017). Instruments for gathering data. In E. Moore \& M. Dooly (Eds), Qualitative approaches to research on plurilingual education (pp. 390-401). Research-publishing.net. https://research-publishing.net/book?10.14705/rpnet.2017. emmd2016.9781908416476

Cavanagh, S. (2016). The Spark of Learning : Energizing the College Classroom with the Science of Emotion (Vol. First edition). West Virginia University Press.

Creswell, J. (2013). Qualitative Inquiry \& Research Design: Choosing Among the Five Approaches. SAGE Publications.

Krashen, S. (1986). The Input Hypothesis Issues and Implications. Longman.

Rogers, C. (1977). Carl Rogers and Humanistic Education. http://www. sageofasheville.com/pub_downloads/CARL_ROGERS_AND_ HUMANISTIC_EDUCATION.pdf

Schûtz, R. (2019). Stephen Krashen's Theory of Second Language Acquisition. https://www.sk.com.br/sk-krash-english.html

Sole, Y. (1994). The Input Hypothesis and the Bilingual Learner. Bilingual Review, 19(2), 99-110.

Universidad Nacional. (2015). Cuestionario Estudiantes Regulares (RO.2). Autoevaluación de la carrera de Bachillerato en la Enseñanza del Francés [Unpublished manuscript]. Escuela de Literatura y Ciencias del Lenguaje-División de Educología

Universidad Nacional. (2018). Informe de Autoevaluación para reacreditación. Bachillerato en la Enseñanza del Inglés [Unpublished manuscript]. Escuela de Literatura y Ciencias del Lenguaje-División de Educología.

Universidad Nacional. (2019). Ámbito institucional. https://www.transparencia.una.ac.cr/index. php?option $=$ com_content $\&$ view $=$ article $\&$ id $=298 \&$ Itemid $=742$ 
